MH EK Neurológiai, Alvásdiagnosztikai és Terápiás Centrum

\title{
A több müszakos munkavégzés következményei a cirkadián alvás-ébrenléti ritmusra
}

\section{Dr. habil Szakács Zoltán orvos ezredes, PhD}

\begin{abstract}
Kulcsszavak: belső óra, cirkadián ritmus, fény, melatonin, anyagcsere, több müszakos munka
\end{abstract}

\begin{abstract}
A belső cirkadián óra csak lassan alkalmazkodik a különböző müszakidők gyors változásaira. $\mathrm{Ez}$ a ritmikus fiziológiás rendszerek, például az alvás, éberség, teljesítmény, anyagcsere, valamint a hormonális müködések, például a melatonin és a kortizol deszinkronizációjához vezet. Mindezek következménye a krónikus alvásdepriváció, a hangulati életzavara és a csökkent teljesítmény lesz. A több müszakos munkakör hosszútávon emeli a kardio- és cerebrovaszkuláris, valamint a malignus betegségek rizikóját. Különböző stratégiák léteznek a cirkadián deszinkronizáció kezelésére és a cirkadián újrarendezés gyorsítására. A cirkadián rendszer manipulációjának legfontosabb tényezői, a fényterápia, illetve a fény kerülése, a melatonin alkalmazása, illetve az étkezések időzítése.
\end{abstract}

Az alvás általános ismertetése és élettani hatása

Az alvás és az ébrenlét ciklikus váltakozása az élőlények alapvető ritmusa, amely az aktivitás és nyugalom, a lehetö legmagasabb rendü alkalmazkodás, a szervezet belső egyensúlyának fenntartása és a szellemi és fizikai fejlődés folyamatos biztosítása mentén alakult ki mind a törzsfejlődés, mind az egyéni fejlödés során. Alvásunk és ébrenlétünk alatt zajló biológiai és pszichológiai folyamatok szer- vesen kapcsolódnak egymáshoz, egységes folyamatot képezve, melynek tartós, vagy ismételt megszakadása, zavara súlyos következményekkel járhat.

Ez magyarázza, hogy az alvás fiziológiás folyamatának rendellenességei sok esetben ébrenlétünk idején megnyilvánuló anyagcsere, vegetatív és központi idegrendszeri, valamint pszichés zavarokat okoznak. Az alvás sajátos viszonyai között viszont olyan kóros légzési-keringési, mozgás és magatartás jelenségek alakulhatnak ki, amelyek az alvás és 
ébrenlét krónikus, súlyos következményekkel járó zavarát eredményezik. Számos krónikus betegségben szenvedő az alvás viszonyai között váratlanul kerülhet veszélyeztetett állapotba.

\section{Az alvás elektrofiziológiai és poliszomnográfiás jellemzői}

Az alvásfolyamat sokrétűségére, ciklusos szerkezetére utaló információkat az alvó külső megfigyelésével már a múlt század végén is szereztek a kutatók. Az alvás pontos, részletes és tudományos jellegü vizsgálatát azonban csak speciális módszerek több lépcsőben történő kialakulása tette lehetővé.

\section{A NonREM és a REM alvás}

$\mathrm{Az}$ alvás két, egymástól és az ébrenléti állapottól eltérő fiziológiai állapotot foglal magában: a paradox vagy REMalvást, illetve a lassú hullámú, ortodox vagy NonREM-alvást. (A REM-alvás nevét a mozgásvihar formájában jelentkező gyors szemmozgások angol megfelelőjének - Rapid Eye Movement - rövidítéséből kapta).

\section{A NonREM alvás}

Az alvás változékony állapotok során alakul ki. Ez a változékony és összetett átmenet az éber állapot és az alvás között, fiziológiás helyzetben az alvásszükséglet szubjektív megélésével, az álmosságérzettel kezdődik és a szendergés állapotán keresztül vezet az alvásig.

\section{A REM alvás}

$\mathrm{Az}$ alvó ébreszthetősége a NonREMalváshoz viszonyítva rosszabb. Jellemzőit ún. tónusos illetve fázisos jelenségekre osztjuk.

\section{Az alvás mintázata, az alvásszerkezet}

$\mathrm{Az}$ alvásfolyamatban az egyes fázisok jellegzetes, program szerinti sorrendbe szerveződnek, kialakítva az alvás ciklusos szerkezetét. Az alvás élő, változó, környezeti és belső ingerekre reagáló dinamikus folyamat, számos fázisok közötti oszcillációval. Az egyes alvásstádiumok leírásából is kiderül, hogy azok között nincs borotvaéles határ. Éppen ezért az alvásszerkezet ábrázolásának, amely nem más, mint a háttérben lévő alvásprogram mintázata sokféle típusa létezik. A gyakorlatban az alvás makrostruktúrájával foglalkozunk elsősorban.

A hipnogram úgy jön létre, hogy az alvást koordinátarendszerben ábrázoljuk, ahol a vízszintes tengelyen az időt, a függőleges tengelyen - egyezményes skálán - az alvásstádiumokat tüntetjük fel előfordulásuk sorrendjében és tartamuk szerint. A hipnogram lényegében a csak részleteiben megismert alvásprogramnak a mennyiségi-képi ábrázolása. Fiziológiás esetben elalvás után mélyülő, majd fokozatosan felszínessé váló sorrendben a NonREM-alvás stádiumain keresztül jutunk el az első REM fázisig. Így válik teljessé egy alvásciklus. Tartama átlagosan 90 perc és egy éjszakai alvás során 4-6 alkalommal ismétlődik, jellemzően változó összetétellel: az alvás első harmadában egy cikluson belül a mély NonREM-alvás dominál, majd fokozatosan háttérbe szorul, a NonREMalvás a későbbi ciklusokon mind felszínesebb lesz.

A REM-alvás ellentétes utat jár be: az alvás második felére e fázis mind tartamban, mind denzitásban növekedést mutat. A naponta alvással töltött idő, illetve az alvás szerkezete az életkorral párhuzamosan jellemző módon változik. Egészséges fiatal felnőtt naponta 6-8 
órát tölt alvással, amelynek a REM-alvás 25, a felszínes NonREM-alvás 55, a mély NonREM-alvás $20 \%$-át teszi ki. Az újszülött naponta 16-18 órát alszik, a napi alvásigény 1 éves korra 12 órára, 10 éves korra 10 órára, serdülő korra 8 órára rövidül. 40 év felett ez az alvásigény ismét csökkenni kezd, 60 éves kor körül már naponta 5-6 óra alvás is elegendő.

Újszülöttekben a NonREM alvást az ún. nyugodt alvás a REM alvást az aktív alvás helyettesítik, amelyekből 1 éves kor körül fejlődik ki a REM és NonREM alvás. Csecsemő-, gyermek- és felnőttkorban a REM- és mély NonREM-alvás aránya meghaladja a fiatal felnőttkorban észlelt arányokat. A REM alvás aránya újszülött kortól az első életév végéig 50\%ról 25-30\%-ra csökken. A NonREM alvás részaránya pubertás korig némi emelkedést mutat, benne gazdagodik az alvási orsó tevékenység. Magasabb életkorokban ugyanakkor e két alvásforma mennyisége - föleg a mély NonREM alvás - fokozatosan csökken.

$\mathrm{Az}$ újszülött csaknem az egész napot átalussza. Kisgyermekkorban alvásunk jellemző módon kétpólusúvá válik, a napi alvásmennyiség egy hoszszabb éjszakai és egy rövidebb kora délutáni szakaszra oszlik. Felnőttkorban a délutáni alvás - az emberek túlnyomó többségében környezeti, szociális hatások eredményeként - visszaszorul, idős korban azonban, nemegyszer a felszínes és rövid éjszakai alvás kiegészítőjeként, ismét megjelenik. Az alvás szerkezete igénybevétel és környezeti behatások szerint is változhat, a fizikai és szellemi megterhelésnek megfelelően elsősorban a mély lassú hullámú alvás és a REM-alvás mennyisége növekszik. Ez a képesség az életkor növekedésével fokozatosan csökken.

\section{Az alvás-ébrenlét szabályozás homeosztatikus, cirkadián és ultradián komponensei}

$\mathrm{Az}$ alvás és az ébrenlét váltakozása, az alvás szerkezeti jellemzői, a hozzájuk csatlakozó anyagcsere és hőmérsékletmutatók egyaránt arra utalnak, hogy az alvás kialakulásában több, mind az alkalmazkodást, mind a homeosztázist segítő egymással szoros kapcsolatban müködő szabályozó mechanizmus vesz részt. A változások leírása, humán és állatkísérletek három alapvető tényezőt, $\boldsymbol{a}$ homeosztatikus, a cirkadián, illetve az ultradián komponens létét igazolták

A homeosztatikus komponens a mély NonREM-alváshoz kötődik, lényegében szabályozza az ébrenléti aktivitás tartama (minél tovább vagyunk ébren, annál álmosabbak leszünk) és az azt követő restoratív mély (lassú delta) NonREM-alvás menynyisége közötti fiziológiás egyensúlyt hivatott fenntartani. Abban nyilvánul meg, hogy az ébrenléti aktivitás tartamának és intenzitásának függvényében - egy exponenciális görbe mentén - megnövelt lassú hullámú alvásmennyiséget biztosít a követő alvás során. A mély lassú hullámú alvás pótlása - a REM-alvás pótlásával szemben - napszaktól függetlenül, ellenállhatatlanul következik be. Ma már bizonyított, hogy a lassú hullámú alvás viszszacsapásos pótlása leginkább a homlok lebenyt, a domináns agyféltekét és az aktuálisan túlterhelt agyi régiókat érinti.

\section{A cirkadián és szemicirkadián kom-} ponens eredménye, hogy alváskészségünk nem egyformán oszlik el a nap során, hanem két kiugró pontot mutat 24 és $04 \mathrm{~h}$, illetve 14 és $17 \mathrm{~h}$ között. Ezt a két időszakot elsődleges, illetve másodlagos alváskapunak is nevezik. Alváslaboratóriumi kísérletes helyzetben az is kiderült, hogy a 08-10 és a 17-19 óra közötti 
időszakok - a cirkadián alváskésztetés csökkenése következtében - viszont az ébren maradásnak kedveznek. Az éjszakai csúcs a maghőmérséklet mélypontjával, a napközbeni csúcs a maghőmérséklet koradélutáni átmeneti csökkenésével jelentkezik egy időben. Az alvás 24 órás mennyiségének egy tömbben való jelentkezése a cirkadián szabályozás eredménye. Hatása abban is észlelhető, hogy az elkezdődött alvás tartamának is határt szab. Minél közelebb kezdődik az alvás az éjszakai maghőmérséklet mélypontjához, annál rövidebb ideig tart.

A délutáni csúcs a szemicirkadián komponens megnyilvánulása. A tartósan virrasztó, majd alvó személy alvásának homeosztatikus potenciálja (lassú delta hullám tartalma) ekkor a legnagyobb. Az itt megjelenő alváskésztetést sokáig az étkezéskor felszabaduló peptidek és az inzulin mobilizáció hatásának tulajdonították. Ma már tudjuk, hogy ez központi szabályozás része. Az is kiderült, hogy a 24 óra során elfoglalt pozíciója az éjszakainál stabilabb. E két időpontnak nagy gyakorlati jelentősége van. Minden alvásmegvonásból, illetve kóros okból ki nem elégített (a nap 24 órájára vonatkozó) alvásigény, ezekben az idöszakokban akarattól független elalvás, enyhébb esetben különbözö mértékben befolyásolható álmosság, vagy figyelemzavar formájában spontán törhet elö. Következményük jelentös teljesítménycsökkenés, illetve balesetveszély lehet.

Az alvás és ébrenlét egyénre jellemző cirkadián ritmusa a gyermek- és iskoláskoron keresztül a fiatal felnőttkorig épül és rögzül a környezet időjelző, időhatároló, életritmust befolyásoló tényezőinek hatására. E két komponens természetes a mediterrán emberek életvitelében, de nálunk is gyakran követhetik olyan foglalkozást üzők, akiket nem köt a megha- tározott munkarend. A délutáni lehetőség kihasználása életkor függő is lehet. Az óvodáskorú gyermek azért alszik délután is, mert az éjszakai alvásmennyiség nem elégséges számára. Az idős ember, kevesebb napközbeni elfoglaltsági kényszer híján éjszakai, természetesen felszínes és rövid alvását pótolja. E komponensek szempontjából természetesen a „fiziológiás" helyzet a napközben aktív, éjszaka pihenő életvitel. Az egyén cirkadián ritmusa az életkorral párhuzamosan csökkenő mértékben tartós környezeti hatásra módosulni képes. Tartós éjszakás müszakban dolgozó fiatal felnöttek teljesítménye akkor „áll be”, amikor maghömérsékletük profilja is megfordul.

$A z$ ultradián komponens, amely éjszaka 90, nappal 120 perces ciklusokat képez, legszembetűnőbb módon az alvás szerkezetében, a NONONREM-REM ciklusos váltakozásában nyilvánul meg. Az ultradián ritmus ébrenlétben a gyermek- és felnőttkor során fokozatosan háttérbe szorul és csak az éjszakai alvás marad fenn. Az alvás első harmadában a homeosztatikus NONONREM igény - jelentős lassú alvás túlsúlyt okozva - „szétfeszíti” az ultradián komponens kereteit, ami aztán fokozatosan az alvás utolsó harmadában kerül következetesen elötérbe. E jelenségnek praktikus oka lehet: a REM funkciók a NONONREM folyamatok eredményeire épülnek. Más szóval a REM alatti folyamatok eredményességének feltétele a NonNREM-alvás alatti restoratív, energia megörző, szintetizáló folyamatok maradéktalan befejezése.

\section{Az alvás- ébrenlét ritmus cirkadián szabályozása}

A biológiai folyamatok cirkadián (24 óra körüli) ritmusa a Földön kialakult élővilág általános jellemzője. Ember- 
ben a legszembetűnőbb cirkadián ritmusnak a naponta visszatérő, bifázisos ébrenlét-alvás ciklusok számítanak. Az alvás-ébrenlét ciklicitás a belső óránk (az elülső hypothalamusban található nucleus suprachiasmatis) müködésén alapul, ami számos egyéb élettani paraméter (testhőmérséklet, cortisol és melatonin vérszint) cirkadián ritmusát is vezérli. A belső óránk hatását az endokrin hormonok és a vegetatív idegrendszer ritmusai közvetítik a periféria felé. A szervezet fiziológiás működésének alapfeltétele, hogy ezen ritmusok szinkronizáltan müködjenek, így a 24 órás nap egyes szakaiban a legjobb alkalmazkodást lehetővé tevő kombinációkat (ún. „state”-eket, állapotokat) képezzenek.

A cirkadián ritmusok endogének, a környezet időhatározó tényezőinek tartós kiiktatása esetében is fennmaradnak. Emberben az endogén alvás-aktivitás ritmus 24.3 óra körül van, ami azt jelenti, hogy a környezet időhatározó („Zeitgeber”) tényezői, elsősorban a fény, étkezés, valamint a fizikai-szellemi aktivitás révén naponta igazodik hozzá a 24 órás ritmushoz.

$\mathrm{Az}$ alvás-ébrenlét cirkadián szabályozásában a melatonin rendszer is fontos szerepet kap. A melatonin vérszint emelkedése (kb. 2 órával a megszokott alvás kezdete előtt kezdődik, csúcspontját 0 és 2 óra között éri el).

A melatonin tirozinból képződik, a tirozin hidroxiláz enzim aktiválódása révén. Ezt a folyamatot sötétség és nyugalom serkenti; fényhatás, ébresztő inger, a szimpatikus aktivitás növekedése, az adrenalin és a hisztamin gátolják. A melatonin javítja az alvás stabilitását és támogatja a reprodukciós folyamatokat.

\section{Az ultradián szabályozás ma ismert tényezői}

Az ultradián ritmus az alvásszabályozásnak az egyén életében legkorábban megjelenő (a magzati élet utolsó harmad, újszülöttkor) formája, ami kezdetben a nap 24 órája során folyamatosan nyilvánul meg, később pedig napközben az ébrenlét nyomja el, bár a vegetatív szabályozásban, féltekei dominanciában ezen idő alatt is észlelhető.

\section{Az alvás-ébrenlét ritmus cirkadián szabályozásának zavarai}

Az alvás-ébrenlét zavarok cirkadián szabályozás zavarainak jelentősége annál jobban nőtt, minél jobban elötérbe került a modern szervezettségü iparosodás, a korszerű légi-közlekedés, fontosabbá vált bizonyos társadalmilag nélkülözhetetlen tevékenységek (egészségügy, szállítás, fegyveres erők stb.) folytonossága. Létrejöttek e területeken a feladatorientált és feladatvezérelt, eltérő szervezettségű többműszakos munkakörök, megnőtt az e viszonyok közepette megkövetelt magas szintű szellemi munka követelménye és felismertük az esetleges balesetek, tévedések súlyos következményeit is. Jelentős tényező volt a modern légi közlekedés során megjelenő időzóna-váltás szindróma is (Jet-lag).

Nem véletlen tehát, hogy ezen alvászavar csoport kutatására alakultak elsősorban az állami és tőke támogatottságot élvező kutatóhelyek, intézetek, és fejlődnek rohamosan olyan részterületek, amelyek a molekuláris biológiától kezdve, a munkaegészségügyön, a hadtudományokon, a közlekedésszervezésen keresztül számos más területtel fennálló szoros együttmüködésen alapulnak, középpontjukban a kronobiológia tudományával. 
$\mathrm{Az}$ e körbe tartozó problémák teljes körü diagnosztikája és terápiás arzenálja egy, a korszerü követelményeknek minden szempontból megfelelö alváscentrumtól is speciális képzettséget és készségeket követel meg [1].

\section{Az alvás-ébrenlét ritmus szabályozása}

A biológiai kutatás évtizedekkel ezelőtt felismerte, hogy a Földön kialakult élet minden fejlettségi szintjén a változó környezethez való alkalmazkodást és az állandóságot egyaránt biztosító, reguláló rendszerek alakultak ki. A változó környezethez akkor biztosítható a legjobb és leggazdaságosabb alkalmazkodás, ha a szervezet alapvető (ébrenlétet, nyugalmat, keringést, hőszabályozást és számos egyéb, hormonális és autonom területet egybefüző, szinkronizáló) működései a biológiai órában (Supra Chiasmatis Nucleus-ban és kapcsolataiban) megörződnek. Lényegében ezek a tárolt jellemző együttállások („state”-ek) képezik alapját a belső, szerkezetében is összetett endogén biológiai óra programjának.

Környezetünk életfeltételeket befolyásoló változásai alapjaiban a Föld egy körbefordulásának idejével, azaz a nap 24 órájával kapcsolatosak. Nem véletlen tehát, hogy endogén biológiai ritmusaink leginkább meghatározó elemei a cirkadián ritmusok, domináns időhatározó faktorai pedig a változó környezeti fényviszonyok. A domináns cirkadián óra vezérli és szinkronizálja az ébrenlét és alvás közbeni magatartást, a hormonális és vegetatív idegrendszeri szignálokat, befolyásolja a perifériás szervi és sejtszintű oszcillátorok működését.

Endogén cirkadián biológiai óránknak két fö inputja van, amelyek az aktuális környezeti feltételeknek megfelelően időtagoló hatásuk révén 24 óra köré állítják be alvás és ébrenlét ciklusunkat.

Ezeket a tényezőket időtagoló-közlő hatásuk alapján német szóval „Zeitgeber” tényezőknek nevezzük

1. A fény, illetve fény/sötét változások,

2. A nem fotikus tényezők.

1. A teljes fehér fény intenzitását 10 lux alatt sötétségnek, 50 lux alatt homálynak, 500 lux alatt gyenge, 10001500 lux között jó, 2500-10 000 lux között terápiás szintként ismerjük. A fény biológiai órára gyakorolt hatását jelentősen módosíthatja a szemlencse, az üvegtest állapota és pupilla fényreakciójának aktivitása is.

A látóideghártya (retina) idegsejtjeinek egy része melanopsint tartalmaz, ami fényhatásra erősen ingerlődik a 450-470 nanométer frekvenciájú fény hatására. Ezek az idegek elérik a belső óránkat. Ez a kellemes halványkék fény aktiválja a legerősebben a belső óránk sejtjeit és gátolja a melatonint termelő tobozmirigyet [2].

2. Emberben a szociális környezet hatása igen erős. Életmódunk, az ehhez tartozó étkezési és munkarend, valamint számos olyan környezeti jel (TV, rádió, hirdetések, a megszokott környezet aktivitásának megnyilvánulásai stb.) amelyek napirendünk folyamatos tudatos és tudattalan közlését valósítják meg. Ez a faktor nem csupán a központi idegrendszerben, hanem a meghatározó szerveken, helyileg is kifejti hatását, föleg az étkezések révén, melyeknek endogén és jelentős maszkírozó hatása is van.

\section{A „free-running” effektus}

A külső befolyások minimalizálása úgy lehetséges, hogy a környezeti fény egyenletesen 300-500 lux közé csökkentése 
mellett megfosztjuk a kísérleti személyt minden időtagoló befolyástól is. Ez a „free-runnig” állapot, olyan izolált élethelyzetet jelent, ahol az illető szabadon választhatja meg mikor kel, mikor fekszik, mikor étkezik, vagy tisztálkodik. Ebben a kondícióban derült ki, az alvás-ébenlét ritmus és a maghőmérséklet szabályozás két különböző generátor köré szerveződik. A kísérletes szituációban mindkét ritmus 2 nap múltán folyamatosan késni kezdett, a maximum előbbinél 3-5, utóbbinál 6-9 óra volt. Az adrenalin profil az alvás-ébrenlét profillal maradt együtt.

Összességében kiderült: Belső alvásébrenlét ciklusunk ritmusa nem pontosan 24 óra, és bizonyított lett az is, ezek a ritmusok számos hierarchikus szinkronizációs kapcsolattal füződnek egymáshoz. Az endogén alvás-ébrenlét ritmus értékek 23,5-24,8 óra között szórtak, nőkben és afro-amerikaiakban, valamivel rövidebb átlagértékekkel.

\section{Az endogén biológiai óra és a külső, időtagoló tényezők interakciója}

A biológiai óra másik fontos feladata, hogy külső behatások esetén módosítsa a már rögzített programjait, azaz alkalmazkodjon az új helyzetekhez. Az alkalmazkodási képesség (kapacitás) természetesen a kihívástól, azaz az új környezeti fény- és aktivitás feltételek formájától, azok expozíciós idejétől, az alkalmazkodás gyors kényszerétől vagy fokozatos lehetőségétől is függ.

$\mathrm{Az}$ alkalmazkodási kapacitás az életkor növekedésével fokozatosan beszükül. 20 éves korig alakul, 20-50 évek között beáll, 50 éves kortól fokozatosan veszti rugalmasságát. Az alkalmazkodás összetettségét jelzi, hogy még egészséges fiatal felnőttek számára is 7-14 napnak kell eltelnie ahhoz, hogy az állandó éj- szakás munkának megfelelöen a maghömérséklet is az új helyzetnek megfelelö profilt mutasson.

$A z$ esti órákban alkalmazott terápiás fény késlelteti, a reggeli órákra pozícionált fény idöben elöre hozza az alvásperiódust és a maghömérséklet ciklusát. A hatást a fény hullámhoszsza, időzítése és intenzitása, különösen a fényterápia tartama befolyásolja. Késő délután, illetve este adott terápiás dózisú melatoninnal is elörehozzuk az alvásperiódust. A fázisok amplitúdója azonban jóval alacsonyabb lesz, a ciklusidő tartama pedig megnövekszik. A reggeli órákban alkalmazott melatonin az alvásperiódus késleltetését vonja maga után. A külső behatásokkal elérhető ciklusváltozás mértéke jelentős egyéni ingadozást mutat:

Az egész szabályozás számos perifériás hibát hordoz idős korban az autonom idegrendszerben és az életfontosságú szervekben. Idősebb korban csökken az alvás-ébrenlét ritmus a melatonin szint és a maghőmérséklet amplitúdója, a menstruáció elmaradásával nőkben a melatonin termelés negyedére csökken.

A belső óránk sejtjeinek jelentős mértékü pusztulását mutatták ki Alzheimerkórban. Ez a tény az állapottal járó fényés ingerszegény környezettel együtt jól magyarázza a betegekre jellemző inverz alvás-aktivitás zavart, ami fényterápiával bizonyos eredménnyel befolyásolható. Melatonin kezelés e betegcsoportban eredménytelennek bizonyult.

$\mathrm{Az}$ endogén óra működésébe számos a perifériás (szervek, sejt szintek) cirkadián oszcillátorai is beépülnek. Szerveink közül elsősorban a máj, a vese, a szív és az aorta müködésében mutattak ki cirkadián ritmus jelenlétét,

A biológiai óra működését perifériás szerv funkciózavara is befolyásolhatja: 
A melatonin lebontása $80 \%$-ban a májban történik. Súlyos májbetegekben kimutatták, hogy a melatonin profil csúcsa kórosan magas, időben késik és jelentősen belenyúlik a délelöttbe.

$\mathrm{Az}$ összetett endogén biológiai óra szabályozása lehet eleve hibásan kódolt (génhibák következtében), de lehet tartós, az átlagos környezeti elvárásokkal ütköző életmód rögzült következménye is. Az állapot az alkalmazkodási kapacitás beszükülésével is jár. Ezeket az eseteket soroltuk korábban a cirkadián alvásébrenlét zavarok intrinsic csoportjába.

\section{A cirkadián kronotípusok}

$\mathrm{Az}$ endogén biológiai óra müködése a cirkadián kronotípusokban nyilvánul meg. Ismerünk reggeli (pacsirta), illetve esti (bagoly) típusú embereket. Előbbiek korán kelnek, aktivitásuk csúcsát a nap első felében érik el. Utóbbiaknál ez a csúcs estére tolódik, későn fekszenek le és későn kelnek. Az egyes típusok népességen belüli megoszlása változó eredményt adott a vizsgált csoport életkora, neme és a vizsgálat helye szerint. Közös jellemző volt, hogy a semleges típusok túlsúlya mellett az esti típust mutató személyek száma magasabb volt a pacsirta személyeknél

\section{Az alvás-ébrenlét ritmus cirkadián szabályozásának zavarai}

A cirkadián alvás-ébrenlét ritmus zavarát a következők jellemzik: Tartós és viszszatérő alvás- és ébrenléti zavar, ami a cirkadián szabályozás rendszerének elváltozásaira vagy az endogén cirkadián ritmus és a külső környezeti tényezők között fennálló disszonanciára vezethető vissza.

A krónikus alvászavar el- és átalvás képtelenséggel, napközbeni aluszé- konysággal, kimerültséggel, depresszióval, vagy mindegyikkel járhat. Súlyos zavarokhoz vezethet mind a munkában, mind a szociális viszonyokban, megnöveli a baleseti rizikót. Igen gyakran emésztőszervi panaszokkal jár.

A cirkadián alvás-ébrenlét zavarok gyakran szövődnek másodlagosan, gyógyszer szedéshez, anyagcseréhez kapcsolódott alvászavar komponensekkel, alvásfüggő légzészavarokkal. Ezek felismerése, megoldása is a terápia nélkülözhetetlen eleme [3].

\section{Felosztás}

9 csoportot különítünk el. Ezeken belül azonban érdemes fenntartani a bevált régi csoportosítást is, ami intrinsic (a szabályozás primer zavara.), extrinsic (külső tényezők: több műszak, jet lag, betegségek, időskori zavarok stb.) különített el. Emellett nem szabad elfelejteni, hogy az idős kor alvászavarainak jelentős részében - az élettani részben tárgyalt - cirkadián komponensek szerepe jelentős. Külön csoportot képez a vakok alvás-ébrenlét zavara is:

1. Késleltetett alvásfázis szindróma (Delayed Sleep Phase Disorder = DSPD).

2. Előrehozott alvásfázis szindróma (Advanced Sleep Phase Disorder $=$ ASPD).

3. Irreguláris alvás-ébrenlét ritmus (Irregular Sleep-Wake Rhythm = ISWR).

4. Nem 24 órás (szabadon futó) típus (Free Running Disorder $=$ FRD).

5. Időzónaváltás szindróma (Jet Lag Disorder $=$ JLD).

6. Többmüszakos munkát kísérő alvászavar (Shift Work Sleep Disorder = SWSD). 
7. Belgyógyászati és egyéb betegségekhez kapcsolódó cirkadian alvásébrenlét zavarok.

8. Nem meghatározott, egyéb cirkadián alvászavar.

9. Gyógyszerekhez, vagy egyéb anyagokhoz kapcsolódó cirkadián alvászavar.

\section{Késleltetett alvásfázis szindróma}

\section{Jellemzők}

- Az éjszakai alvásperiódus késik.

- Az alvásidő viszonylagos állandó.

- Az alvásszerkezet nem mutat rendellenességet.

- A standard környezeti tényezők kényszer hatására krónikus elalvási nehezítettség, reggeli kialvatlanság képe alakul ki.

- Szabadon futó helyzetben (szabadság) a jellemző alvásperiódus pozíció viszszaáll, a beteg kipihent lesz.

- A 24 órás ritmus fennmarad.

- Súlyos konfliktusok alakulhatnak ki a reggeli-délelőtti rendre épülő szociális környezettel.

- Igen sok olyan eset van, ahol a kép gyógyszerhatás, késői kávéfogyasztás, éjszakai internetezés következménye.

- Leginkább fiataloknál fordul elö.

- A maghőmérséklet profil is későbbre tolódik.

- Ki kell zárni az alváskezdeti mozgászavarokat (RLS/ PLMS).

\section{Előrehozott alvásfázis szindróma}

- Az éjszakai alvásperiódus előre tolódik

- Konfliktusok elsősorban az esti elfoglaltságokkal kapcsolatban alakulhatnak ki.

- Többségében idősebb korúak a betegek.
- A maghőmérséklet görbe is előre tolódik.

- Alzheimer-kórban is megjelenhet.

- Egyéb jellemzők az előbbivel azonosak.

\section{Irreguláris alvás-ébrenlét ritmus}

$\mathrm{Az}$ alvás és ébrenlét rövid szakaszokra tagolódik, esetleges. A cirkadián és szemicirkadián ritmus nem ismerhető fel. Az életkornak megfelelő 24 órás alvásmennyiség nem változik. Előfordul pszichózisokban, személyiségzavarokban, Alzheimer-kórban, metabolikus zavarokban (májbetegségek), koponyasérülések után, idős korban gyenge környezeti megvilágítás, szegényes szociális kapcsolatok, látórendszer defektusai következtében. A betegek többsége nem fogja fel kórosnak az állapotát, inkább a teljesítménydeficitre, illetve hangulatromlásra panaszkodik.

\section{Nem 24 órás alvás-ébrenlét ritmus}

A betegek el- és átalvászavarra, elégtelen alvásra és/vagy aluszékonyságra panaszkodnak. A háttérben a környezeti fénysötét ciklusok és az endogén cirkadián ritmus szinkronizációs zavara áll.

\section{Az időzónaváltás szindróma}

Verne Gyula „80 nap alatt a Föld körül" regényének hősei idején az akkori közlekedés alapján még nem ismerhették, mert alapja a modern légi közlekedés: Relatíve rövid idő alatt több időzónát vagyunk képesek átrepülni. Így belső óránk alkalmazkodásában „lekésik". A kiinduló helyen uralkodó, belső óránkban rögzült ritmus és a célállomáson uralkodó környezet elvárásai között konfliktus alakul ki. 
A konfliktus akkor vezethet kóros következményekhez, ha minimum 3 idözónát repülünk át. 6-12 órás időzóna különbség már meghaladja belső óránk alkalmazkodási kapacitását, amelyben a korábban elmondottak alapján nagy egyéni különbségek lehetnek. A panaszok (azaz az alkalmazkodás) időtartama is változó, általában 2-4 nap. A keleti irányba történő repülés sokkal jobban megviseli szervezetünket: Ilyenkor alvásidőnk rövidül elsősorban, nyugati irányban viszont ébrenlétünk hosszabbodik meg. A tünetek a cirkadián alvás-ébrenlét zavarok általános jellemzőinek felelnek meg [4].

\section{A többműszakos munkakörökkel járó adaptációs zavarok}

A többmüszakos (nem standard) munkakörökben a munkavégzés legalább 50\%-a a reggel 8 és délután 4 óra közötti időszakon kívülre esik. E munkakörökben a konfliktus lényege: Tartósan magas teljesítmény igény és jelentős baleseti rizikó, az átlagostól eltérő, szokatlan ritmusban szervezett munkakörök viszonyai között.

$\mathrm{Az}$ Európai Unió 2004-ben végzett felmérése szerint 15 államban a dolgozó népességnek csak egynegyede dolgozik hagyományos, „standard”, nappali rend szerint. A „nem standard” munkarendek szerkezetét elsősorban az adott iparág, közlekedési forma, fegyveres testület teljesítményigénye és a munkafolyamat által diktált követelmények szabják meg. $\mathrm{Az}$ alábbiakat különböztetjük meg, bár ismert, hogy igen sok helyen kevert munkarendet alkalmaznak:

\section{24 órás szolgálat 4-6 órás alvással.}

2. Váltott müszak $2 \times 12$ óra munka $-a z$ éjszakás műszakokhoz arányos pihenőnapokkal.
3. Forgó (rotáló) müszak $/ 3 \times 4,3 \times 6,3 \times 8$ órás/ változatai.

4. Állandó éjszakás műszakformák.

5. Egyéb, rendezetlen müszakbeosztások.

Bizonyos műszakformák esetében (24/7/, forgóműszak) már vannak olyan felismert biológiai ritmus sajátosságok, amelyek előnyt jelentenek az adott munkakörben. Ilyenek a későn fekvő, illetve a flexibilis kronotípusok. Ismert az is, hogy a forgóműszak előreforgó változata sokkal jobban türhető, mint az óramutató forgásával ellentétes irányú változatok. A többmüszakos munkakörökhöz való rossz alkalmazkodás gyökere a biológiai ritmus torzulása mellett a betegek nagy részében a szociális, családi konfliktusok szintjén keresendő. A krónikus alvászavar kialakulásának megelözésében jelentős szerepe van a munkafolyamatokat szervező és irányító, munkaegészségügyi és munkaszervező oldalnak is.

\section{Az elöfordulás gyakorisága (prevalencia)}

A Többműszakos Munkarendhez Társuló Alvászavar betegség (SWSD) prevalenciájára vonatkozó adatok szerteágazóak. Többmüszakos dolgozók körében az Amerikai Alvás Akadémia 2007-ben az USA-ban $5 \%$-ra becsülte. Német és angol adatok szerint a forgó és állandó éjszakás munkakörökben a leggyakoribb (10-23\%). Többmüszakos olajfúró munkások közötti elöfordulása igen magas $23 \%$. Egy norvég felmérés szerint 5400 váltómüszakban dolgozó szakápolónő között 36.6\% szenvedett ilyen jellegü alvászavarban. A prevalenciát befolyásolja a több müszak formája is. Leginkább a folyamatos rotáló müszak és az óramutató járásával ellentétes müszaksorrendek viselik meg a dolgozókat. 


\section{Tünetek}

SWSD-röl akkor beszélünk, ha az adott több müszak körülményei között több, mint egy hónapig állnak fenn a panaszok. $\mathrm{Az}$ alvásképtelenség mellett napközben nem csupán az aluszékonyságra, hanem memória- és figyelem deficitre, kimerültség szindrómára, emésztőszervi, valamint kardiovaszkuláris következményekre számíthatunk. Megnövekszik a baleseti rizikó, a munkateljesítmény csökken. Súlyos dysphoria alakulhat ki. Új adat, hogy több müszakban dolgozó fiatalokban gyakoribb az Sclerosis multiplex.

\section{Kontraindikációk}

Reggeli cirkadián típus, 50 év feletti életkor, emésztőszervi és epebetegségek, pszichiáriai betegség, epilepszia, „alvásfragmentáló" szindrómák, súlyos hipertóna.

\section{Betegségekhez társuló zavarok}

\section{Demenciák}

Az Alzheimer-kórban a belső óránk idegsejtjei jelentős mértékben pusztulnak. Gyakori az irreguláris és az előrehozott alvásfázis szindróma.

\section{Depresszió}

A depressziónak egyértelmü cirkadián vonatkozásai vannak. Jellemző a korai ébredés, a tünetek reggeli súlyossága és estefelé történő enyhülése. A cirkadián jellemzők különösen a szezonális depresszióban szembetünőek, mely forma gyakran jár napközbeni aluszékonysággal. A napközbeni aluszékonyságot és az éjszakai alvás késését esti-reggeli fényterápia rendezi. Melatonint depresszióban nem alkalmazunk.

\section{Az alvás-ébrenlét ritmus cirkadián zavarainak terápiás lehetőségei}

A cirkadián alvás-ébrenlét zavarok kezelésében az alváshigiénés szabályokat, kronoterápiát, melatonin és fényterápiát, illetve ezek kombinációit alkalmazzuk. Hatékonyságukat illetően az összegyült tapasztalatok alapján az Amerikai Alvás Akadémia 2007-ben különböző szintü ajánlásokat fogalmazott meg, amelyek azóta is érvényesek.

\section{Alváshigiénés szabályok}

Betartásuk a megelőzés egyik eszköze.

\section{Kronoterápia}

Súlyos esetekben a környezettől lényegesen eltérő belső ritmust izolált környezetben mesterséges aktivitás-, alvás és étkezés rend segítségével fokozatosan (naponta és óránként) közelítik a reális környezet rendjéhez. A közelítés sorrendjének délelőtt-délután-éjszaka irányúnak kell lennie. A módszer három részből áll:

1. Diagnosztikai felmérés.

2. Átállítás.

3. Stabilizálás. Tartama egyéni, de általában 3-5 hetet is igénybe vehet.

\section{Otthoni kronoterápiás tanácsok}

Enyhébb esetekben nem szükséges a páciens teljes izolálása. Megfelelő együttmüködési lehetőség esetén sikeres lehet az alvásidő fokozatos (1-2 órával) történő előrehozása, vagy késleltetése néhány napos tartamban. A módszer leginkább a jet lag esetében, melatoninnal, fényterápiával kombinálva válik be. 


\section{Fényterápia}

A terápiás fehér fény erőssége 250010000 lux között van. Ma már kihasználják azt a felismerést, hogy a halványkék fény (450-470 nanométer), 2500 lux erősséggel is hatékony. A kezelést fénytáblával, modern módszerekkel speciális szemüvegbe illesztve alkalmazzák fél-két órás tartamban. A fényterápia időbeli pozíciója határozza meg az alvásciklusra gyakorolt hatást: Esti kezelés késlelteti, reggeli terápia előre tolja az alvásperiódust, egyben fokozza a délelőtti vigilitást. Mind inkább bebizonyosodik, hogy a fényterápia tartama jelentősebb a kiváltott hatásban, mint a fény intenzitása.

Többműszakos munkakörökben, szezonális depresszióban és ingerszegény környezetben élő idősek kezelésében jól bevált. Alzheimer-kórban szenvedők vigilitását is javítja, a zavartságot csökkenti. A fényterápia kezdetekor szemészeti vizsgálat nélkülözhetetlen. Lényegében a fényterápiához sorolható a környezet elsötétítésével, vagy fényelnyelö szemüveg viselésével elért időszakos, pozícionált fénymegvonás is (5 luxnál kisebb környezeti megvilágítás).

\section{Melatonin kezelés}

A terápiás mennyiség általában $3 \mathrm{mg}$, melynek időzítése az adott kórismétől függt. Stabilizálja az alvásperiódust. Idős korban, májelégtelenségben, veseelégtelenségben szedése esetén óvatosság szükséges. Jet lag-ban, többmüszakban és vakok alvászavarának kezelésében jól bevált. Alzheimer-kórban nem hatékony, depresszióban nem alkalmazzuk.

\section{Komplex tréningek}

A krono-, fény- és melatonin terápiát gyakran összerendezett tréningben alkalmazzák. Ezek a módszerek különleges foglalkozási ágakban, különösen a jet-lag megelőzésében használatosak

\section{Szürések}

Ugyancsak speciális munkakörökben alkalmazzák. Szerepük az említett kontraindikációk kiszürése, az alkalmasok kiemelése, rásegítő alkalmazkodási tréningek kidolgozása.

\section{Munkaköri szabályok}

A modern iparban, közlekedésben, fegyveres erőkben, egészségügyben már világossá vált, hogy a viszonyokat úgy kell szabályozni, ne feszítsék túl a tréningekkel is támogatott alkalmazkodási kapacitás határait.

Számos üzemben szigorú munkarendi szabályok vannak már a dolgozók egészségének és teljesítményének megőrzése érdekében.

Forgóműszakban az igen rövid ciklusok (1-1-1, 2-2-2 napok) alkalmazását javasolják, amit éjszakai műszak zár le, az éjszakai müszakok számának kétszeresét kitevő pihenőnapokkal. A forgás délelőtt-délután-éjszakai sorrendjét be kell tartani [5].

Éjszakai műszakban a délelőtti hoszszabb és az éjszakás munka elötti rövidebb alvást preferálják. Mindezekhez a megfelelő étkezési rendet is szabályozzák.

A 24-72 órás munkarend csak néhány munkakör igényeit elégíti ki. Ebben az esetben a résztvevők számára váltásban 4-6 óra alvást engedélyeznek.

Az elalvásos közúti és vasúti balesetek jelentős növekedése hasonló intézke- 
dések meghozatalát hozta a közlekedés föszereplői (kamionvezetők, távolsági busz- és teherautóvezetők, vonatvezetők) esetében is Európában.

$\mathrm{Az}$ 561/20066/EK rendelet védi és egyben ellenőrzi is az aktív vezetés, a monotónia, a megfelelő pihenés és napi alvás mennyiségét. Minimalizálni próbálja azt a terhet, amit e munkakörök jelentenek a komplex biológiai szabályozásra. Az 561/20066/EK rendelet szerint 5 hét munka után 2 hét szabadság, 24 óránként 11 óra alvás, 4-5 óra vezetés után 45 perc szünet betartása kötelező, és ezt tachográffal ellenőrzik $[6,7]$.

\section{Hogyan optimalizáljuk az éjszakai müszakok rendjét? \\ (Útmutató, hogyan küzdjünk meg a többmüszakos munkarend nehézségeivel)}

Alapvető fontosságú, hogy a csak éjszakai dolgozók megtanulják, hogyan kezeljék nappali alvásukat. Bevezetőül rögtön néhány jó tanács: kapcsolja ki a mobiltelefont, húzza ki a vezetékes telefont, és fontolja meg a "Nem zavarj” felirat felállítását a hálószoba, vagy a lakás ajtaján. A hálószoba a ház csendesebb részében legyen. Beszéljen a szomszédokkal, és tudassa velük, hogy éjszaka dolgozik. Hagyjon egy kis időt a lefekvés előtt relaxálni, amikor éjszakai müszak után hazatér (mint, ahogyan egy napi müszak után is). Ne essen pánikba, ha nem tud aludni Ha még nem dolgozott az éjszakai müszakban, kérdezze meg kollégáit a megküzdési tippekről, de ne felejtse el követni a lenti ajánlásokat is.

\section{Rögzített, vagy forgó müszakváltás}

Egy ideális világban mindannyian nappali órákban dolgoznánk, de ha ez nem lehetséges, általában jobb, ha legalább két hétig vagyunk egy stabil rutin mellett, mint inkább, hogy gyakran változtassuk. A gyorsan változó, forgó műszak olyan - mint egy állandó jet-lag - mintha minden nap egy másik kontinensre repülnénk. Minél több időnk van a különböző műszaktípusok között alkalmazkodni, annál jobb.

\section{Forgatás az óramutató járásával megegyező irányban}

A legtöbb embernek alvási-ébrenléti ciklusát könnyebb változtatni, ha ébrenlét időt hosszabbítjuk és nem rövidítjük. Más szavakkal kevésbé zavaró a nappali müszakokról az esti müszakokra, majd az estiről az éjszakai müszakokra történő váltás, mintsem a fordított irányban.

\section{A hosszabb müszakok hosszabb idejű regenerálódást igényelnek}

A hosszabb időtartamú, több mint 8 órás munkát igénylő műszakok általában kifejezettebb álmossággal és jóval nagyobb baleseti kockázattal járnak. Fischer és munkatársai 2016-ban kimutatták, hogy egy olyan müszakrendben, ahol egy 12 órás nappali müszakot 24 órás szabadidő, majd egy 12 órás éjszakai müszak és két teljes pihenőnap követ, az alvás, a munkabiztonság és a fáradtság szintje hasonló a folyamatos 8 órás nappali müszakéhoz.

\section{Pacsirták és baglyok}

Ha valaki mindig is korán ébredt és reggelenként jó energia szintet érez, akkor valószínüleg könnyebb lesz alkalmazkodnia a kora reggeli müszakhoz, mint a termé- 
szetszerűen „éjszakai bagolynak”. A munkáltató legyen rugalmas és merjen kísérletezni legalább egy hónapig a különféle típusú műszakokkal. Amikor az alkalmazott megtalálta a neki leginkább megfelelőt, tegye lehetővé, hogy az ragaszkodhasson kiválasztott műszakhoz.

\section{Van másik lehetőség?}

Egyeseknek könnyebb alkalmazkodni a munkaidőváltásokhoz, mint más munkavállalóknak. Ha a belső óránk lassan és nehezen állítja át szervezetünket, akkor különösen óvatosnak kell lennünk alvásidőnk védelmében és be kell ismernünk, hogy csak rendszeres nappali müszakban vagyunk képesek dolgozni. Ha nincs lehetősége megváltoztatni a müszak beosztását, nagy figyelmet és fegyelmezettséget kell tulajdonítani annak, hogy mit csinál a müszak elött, alatt és után, ugyanis ezek függvényében óriási különbségek lehetnek az álmosság érzésben és a hangulatban. Ezek a tippek hasznosak lehetnek az esti és éjszakai müszakokban is. Tesztelje, mi müködik leginkább az Ön számára az alábbiakban és próbálja meg ezt gyakran és rendszeresen végezni.

\section{Az éjszakai múszak előtt}

A legtöbb ember könnyen megbirkózik alvás ébrenléti ciklusuk 2-3 órás időeltolódásával. Ha van néhány napunk az éjszakai műszak megkezdése előtt, fokozatosan toljuk el az alvás és ébrenléti időket az új ütemterv felé, például úgy, hogy minden nap 2 órával később keljünk fel, és 2 órával később menjünk ágyba aludni.

Szundikáljon a müszak elött, hogy így csökkentse az álmosságát munka közben.
Ha veleszületetten rendszeres korán kelö, „pacsirta”, próbáljon meg egy, legfeljebb 3 órás szundikálást beiktatni az alvásadósság csökkentésére. Ha a munkavállaló éjszakai bagoly, akkor jóval nehezebb lesz délután aludni, de ennek ellenére próbáljon ki legalább egy 15-20 percet szunyókálnia, mielött a munkába áll.

Legyen tudatában, hogy ha 30-40 percnél többet szundít, akkor a teste mély alvásba kerül. A mély alvás nagy előnye, hogy legjobban csökkenteni az alvásadósságot, de körülbelül egy órát vehet igénybe, mire ismét teljesen éber lesz, tehát erre is hagyjon időt.

\section{Maradjon éber, miközben dolgozik}

Keressen erős fényt az éjszakai müszak előtt és lehetőleg a müszak kezdeti időszakában is. Annak ellenére, hogy a munkaterületek gyengén megvilágítottak, legyenek nagy fényerejü területek is. Ha a munkahelye túl sötét, beszéljen a munkáltatójával és kérje a világítás fényerejének növelését.

Ha néhány napig ugyanabban a müszakban dolgozik, mindennap ugyanabban az időben étkezzen, hogy elösegítse a rendszeres testciklusokat. Ha több napot dolgozik éjjel, akkor tartson „ebédszünetet” és egyen „ebédet” a müszak közepén.

A műszak közepében történő, legfeljebb 30-40 perces „intenzív alvás” jóval hatásosabb az éberség javítására, mint a kávé.

A koffein tartalmú italok, mint például a kávé, és a tea, hasznos stimulánsok lehetnek a figyelem fokozására a müszak első felében, ám a műszakot követő lefekvést követően megnyújtják az elalvási időt, csökkentik a mély alvást és kevesebb alvási órát eredményeznek. 


\section{Hazaérkezés éjszakai műszak után}

Vezetni kell?

Ha éjszakai müszak után vezet, nagy a kockázata annak, hogy autóbalesetet szenved. Reflexei meglassultak, a döntöképessége lassú, pont úgy, mintha alkoholos befolyásoltság alatt lenne. Ha a tömegközlekedés vagy a taxi nem elérhetö, változtatgassa a hazavezető útvonalat, így kevésbé valószínű, hogy „robotpilóta" módban vezet.

A nappali fény azt jelzi, hogy a testének ébren kell maradnia. Ezért hazafelé viseljen sötét szemüveget, hogy ösztönözze a melatonin termelődését és készítse fel testét az alvásra.

\section{Védje az alvásminőségét az éjszakai müszak után}

Ugyanazt a rutint kövesse a lefekvésre való felkészülésben, mint a nappali müszakot követően. Ez a reggel és este azonos lefekvés előtti viselkedésmintázat indukálja testét, hogy készen álljon az alvására. Könnyü étkezés, meleg fürdő, fogmosás, nyugtató zene, relaxációs gyakorlatok vagy meditáció lehet a rutin része.

Kerülje el, hogy olyan óra, vagy ébresztőóra legyen közelében, amit pihenőideje alatt láthat. A gyakori óranézegetés aggodalmaskodással és következményes szorongással járhat.

Használjon elsötétítő függönyt, hogy hálószobája legyen a lehető legsötétebb. Alternatív megoldásként egy jó szemmaszk ugyanazt eredményezi.

Ha zajos környezetben él, hangszigetelje hálószobáját dupla üvegezéssel, szőnyegekkel, nehéz függönyökkel, vagy akár a fal szigetelésével is. A füldugók hozzájárulhatnak a béke és nyugalom megőrzéséhez.
Mobilját kapcsolja ki. Háziállatai ne zavarják alvásában.

Készítsen látható nyilvántartást az alvásáról és munkaidejéről, hogy családtagjai láthassák és ne ébresszék fel véletlenül.

Fontoljon egy figyelmeztetést a bejárati ajtón, hogy jelezze másoknak, hogy müszakban dolgozó munkavállaló próbál aludni, de persze, csak akkor, ha ez megértő fülekre talál.

Altatók használata nem javasolt éjszakai műszak után, mert másnaposság lehetséges és addiktív hatásai vannak (hozzászokás).

Csak akkor szabad kitenni magát erős fénynek, ha készen áll a munkára.

\section{Regenerálódás a müszakok között}

Próbáljon keresni és találjon időt a testmozgásra. Ha képes fizikailag is fit maradni, akkor a teste jobban megbirkózik a testóra változásaival, és összességében kevésbé érzi majd fáradtnak magát.

Ha megpróbál visszatérni a természetes nappali müszakhoz, ne feledje, hogy az erős fény fokozza az éberséget. A nap spektrumát és intenzitását utánozó fényjelző órák és világító dobozok segíthetnek az alvás-ébrenlét ciklusának visszaállításában (cél 2500 lux vs. normál megvilágítás $\sim 150$ lux).

\section{Délutáni alvás}

A délutáni alvás kiemelkedően fontos módja annak, hogy kipihenje magát az éjszakai műszak megkezdése előtt. A müszak előtti két órás alvás csökkenti a fáradtság felhalmozódását, és sokkal könnyebben marad ébren és lesz aktív az éjszaka közepén lévő holtpontok alatt is. 
Aludjon inkább délután, mint éppen a szolgálatba lépése előtt, mert a kora esti órákban a test leginkább éber, így az alvás nehezebb lesz. Ideális esetben ez a pihenés legalább két órán keresztül tartson, hogy magában foglalja a mély alvás jótékony időszakát is.

\section{Erös fény}

Tervezze meg, hogy maximalizálja a fénynek való kitettséget az éjszakai müszakban. Az éjszakai fénynek való kitettség, ideértve a világos asztali lámpa vagy a normál fényszórók beltéri fényét is, ébresztő hatással vannak az agyra és javítják a teljesítményt. Fontos szempont, hogy az intermittáló, időszakos fény expozíció majdnem ugyanolyan hatékony, mint a folyamatos expozíció.

\section{Étkezés este}

Egyen és igyon megfelelően, hogy ne kezdje el éjszakai müszakját éhes vagy kiszáradt állapotban. Éjszaka dolgozva nagyon könnyü elhagyni a megfelelö étkezést, mivel a cirkadián minták befolyásolják az étvágyat, és az étkezde létesítmények elérhetősége korlátozottak, vagy bezártak. Bizonyíték van arra, hogy a magas fehérjetartalmú, alacsony szénhidráttartalmú étkezés a legjobb az éjszakai műszak éberségének fenntartásához. Egyen egy teljes étkezést, mielőtt szolgálatba lépne, a műszak közepén „ebédeljen”, és végül mielőtt lefekszik könnyen emészthető ételt egyen, ha éhesnek érzi magát. Az éjszakai étkezése biztosításához, szerezze be saját ételeit.

\section{Koffein}

A koffeint stimulánsként használják, hogy segítsen ébren maradni. Széles körü használata ellenére a koffeinnek vannak mellékhatásai, és nem helyénvaló ösztönözni a koffeinnel történő visszaélést. A toleranciától függően túl sok koffein emésztőrendszeri zavarokat és izomrángást okozhat. Ezen túlmenően nem szabad legalább négy órával az éjszakai műszak vége előtt alkalmazni, mivel annak tartós hatásai miatt nehezebben tud a hazaérés után elaludni. Ha úgy dönt, hogy koffeint használ az éberség fokozására, akkor a legjobb, ha azt kis mennyiségben fogyasztja. Egy csésze kávé hatása már 20 perc múlva kialakul, és az egyéntől és a kávéfózéstől függően, akár három vagy négy órán keresztül is tarthat. Hasonlóképpen, a koffeint tartalmazó energiaitalok segíthetnek ébren maradni.

\section{Mielőtt lefekszik}

Amikor hazaért, ne engedje, hogy más dolgok késleltessék a lefekvést. Minél tovább késik ezzel, annál inkább éberebb lesz, és annál nehezebben fog elaludni, függetlenül attól, hogy fáradt. Azok a többmüszakos munkavállalók, akik reggel 10-kor lefekszenek, legalább négy órán át alszanak, míg azok, akik délben kezdik, egy órával kevesebbet alszanak. Ha éhes vagy szomjas, mindenképpen egyen és igyon, hogy például a szomjúság miatt felébredve nehogy megszakadjon az értékes nappali alvás. Kerülje az alkohol használatát, mivel bár a hatása elösegítheti az elalvást, az alvás minősége romlik, és hosszabb távon álmatlanságot okozhat. Az alkohol zavarja az alvás mély szakaszát. A következő műszak előtti órákig kerülje el az olyan tevékenységeket, amelyek növelik az éberségét.

\section{Cirkadián mélypont}

Ez az az idő, amikor a test természetes órája a legalacsonyabb 3 és 6 óra között. $\mathrm{Az}$ éjszakai dolgozók ebben az időben 


\begin{tabular}{|c|c|}
\hline Igen & Nem \\
\hline $\begin{array}{l}\text { Alakítson ki egy lefekvés-szertartást, ame- } \\
\text { lyet rendszeresen elvégez, mielött elalszik } \\
\text { - pihenjen egy könyvével, hallgasson zenét } \\
\text { vagy fürödjön. Ez jelzés, üzenet a testének, } \\
\text { hogy a test álljon készen az alvásra. }\end{array}$ & $\begin{array}{l}\text { Kerülje el a stresszes, stimuláló } \\
\text { tevékenységeket, lefekvés elött. }\end{array}$ \\
\hline $\begin{array}{l}\text { Tartsa a hálószobát minél hủvösebben - az } \\
\text { emberek jobban alszanak hüvösebb környe- } \\
\text { zetben }\left(18{ }^{\circ} \mathrm{C} \text { körül). }\right.\end{array}$ & $\begin{array}{l}\text { Kerülje az alkoholt, vagy a nikotint alvás } \\
\text { elött egy-két órával. Az alkohol álmosságot } \\
\text { okozhat, de elalvás után túl gyorsan } \\
\text { felébreszt. A nikotin stimuláns, } \\
\text { és befolyásolhatja az alváshoz szükséges } \\
\text { időt. Ne igyon koffeint legfeljebb négy órán } \\
\text { keresztül lefekvés elött. }\end{array}$ \\
\hline $\begin{array}{l}\text { Az éhség elkerülése érdekében egyen lehe- } \\
\text { töleg könnyü ételt. }\end{array}$ & $\begin{array}{l}\text { Kerülje el a nehéz, vagy zsíros ételeket } \\
\text { lefekvés előtt, mivel ezek nehezebben } \\
\text { emészthetők }\end{array}$ \\
\hline $\begin{array}{l}\text { A napi rendszeres testmozgás segít az alvás } \\
\text { mintázat megtartásában, de kerülje a test- } \\
\text { mozgást körülbelül három órával lefekvés } \\
\text { elött (mert felmelegszik). }\end{array}$ & $\begin{array}{l}\text { Kerülje a tévét, a videojátékokat, } \\
\text { a tanulást, a játékot vagy a számítógépet } \\
\text { a hálószobában. }\end{array}$ \\
\hline $\begin{array}{l}\text { Tartsa sötétben a hálószobát - használjon } \\
\text { szemmaszkot, sötétítő redőnyt vagy nehéz } \\
\text { függönyöket a hálószoba ablakon. }\end{array}$ & $\begin{array}{l}\text { Ne próbáljon erőszakkal aludni - az alvás } \\
\text { passzív folyamat. Ha nem tud aludni, } \\
30 \text { perc után keljen ki az ágyból és tegyen } \\
\text { valamit, amivel elvonja figyelmét. }\end{array}$ \\
\hline $\begin{array}{l}\text { A hálószobában legyen csend - szükség ese- } \\
\text { tén használjon füldugót. }\end{array}$ & $\begin{array}{l}\text { Kerülje az órafigyelést - az órafigyelés } \\
\text { fokozhatja az alvás hosszával kapcsolatos } \\
\text { szorongást. Állítsa be az ébresztést, } \\
\text { ha szükséges, és fordítsa el az órát } \\
\text { a látótávolságától. }\end{array}$ \\
\hline $\begin{array}{l}\text { Irjon egy „tennivalók” listát, mielőtt a háló- } \\
\text { szobába megy, hogy ne feküdjön le aggódva, } \\
\text { hogy másnap elfelejti a fontos dolgokat (egy } \\
\text { toll és papír az ágy mellett szintén segíthet). }\end{array}$ & $\begin{array}{l}\text { Kerülje el a lefekvés előtt a szeretteivel } \\
\text { folytatott nehéz beszélgetéseket, vagy } \\
\text { másokkal a konfrontációs beszélgetéseket, } \\
\text { amikor csak lehetséges. }\end{array}$ \\
\hline
\end{tabular}

hidegnek, remegőnek, hányingert keltőnek, és álmosnak érezhetik magukat. Ez egy normális reakció, mivel a testet ebben az időben kevésbé aktívnak programozták be. Nehéz ébren maradni, föleg ha alacsony a munkaigény. Ilyenkor ajánlatos enni és inni valami meleget (kerülje a koffeint). Ha lehetséges, ütemezzen be egy szünetet ebben az időben.

\section{Irodalom}

[1] American Academy of Sleep Medicine (AASM) International Classification of Sleep Disorders Diagnostic Manual, 2014, Third Edition

[2] Costello et al.: The effectiveness of melatonin for promoting healthy sleep: a rapid evidence assessment of the literature. Nutrition Journal, 2014, 13:106.

DOI: 10.1186/1475-2891-13-106 
[3] Culpepper, Drake, Schwartz and Thorpy: Shift-work Journal of Family Practice Supplement January; 2010, 59(1): S3-S31.

[4] Di Milia et al.: Shift Work Disorder in a random population sample - prevalence and comorbidities, Plos One, 2013, 8(1): e55306

[5] Fischer et al.: A unique, fast-forwards rotating schedule with 12 -h long shifts prevents chronic sleep debt. Chronobiology International, 2016, 33(1), 98-107.

DOI: $10.3109 / 07420528.2015 .1113986$

[6] Schwartz \& Roth: Shift work sleep disorder: burden of illness and approaches to management. Drugs, 2006, 66(18): 2357-70.

DOI: $10.2165 / 00003495-200666180-00007$

[7] Steel Changes in shift work patterns over the last ten years (1999 to 2009). Health and Safety Executive Research Paper, RR887, 2011

\section{Col. Z. Szakács MDMC, PhD}

\section{Consequences of multiple shift work on the circadian sleep-wake rhythm}

The internal circadian clock adapts slowly, if at all, to rapid transitions between different shift schedules. This leads to misalignment (desynchrony) of rhythmic physiological systems, such as sleep, alertness, performance, metabo- lism and the hormones melatonin and cortisol, with the imposed work-rest schedule. Consequences include sleep deprivation and poor performance. Clock gene variants may influence tolerance of sleep deprivation. Shift work is associated with an increased risk of major disease (heart disease and cancer) and this may also, at least in part, be attributed to frequent circadian desynchrony. Abnormal metabolism has been invoked as a contributory factor to the increased risk of heart disease. There is recent evidence for an increased risk of certain cancers, with hypothesized causal roles of light at night, melatonin suppression and circadian desynchrony. Various strategies exist for coping with circadian desynchrony and for hastening circadian realignment (if desired). The most important factor in manipulating the circadian system is exposure to and/or avoidance of bright light at specific times of the „biological night”.

Key-words: Body clock, circadian rhythm, light, melatonin, metabolism, shift work

Dr. Szakács Zoltán o. ezds.,PhD 1134 Budapest, Róbert Károly krt. 44. 